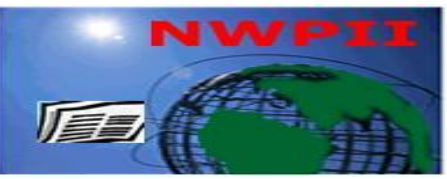

American Journal of Biomedical Sciences

ISSN: 1937-9080

nwpii.com/ajbms

\title{
Cellular Immune Status and Inflammatory Markers in Herpes Simplex Virus Type-2 Sero-positive Pregnant Women
}

\author{
Favour Osazuwa $^{1}$, Nosa O.Eghafona ${ }^{2}$, Rachael Okojie $^{2}$ \\ ${ }^{1}$ Department of Laboratory services, Lily hospitals Limited, Warri, Nigeria. \\ ${ }^{2}$ Department of Microbiology, University of Benin. Benin City, PMB 1154, Nigeria. \\ Corresponding Author \\ Favour Osazuwa \\ Laboratory Services \\ Lily Hospitals Limited \\ Warri, Nigeria \\ Email: favour.newlife@gmail.com \\ Received: 19 January 2016; | Revised: 31 May 2016; | Accepted: 11 June 2016
}

\begin{abstract}
Objective: Herpes simplex virus type-2 (HSV-2) causes genital ulcer disease and has been hypothesized to cause increase in inflammatory markers that contribute to atherogenic process. This study aimed to determine the cellular immune status and levels of systemic inflammatory markers in HSV-2 sero-positive pregnant women attending the antenatal clinic of Central Hospital, Warri, Nigeria. Method: This study included three hundred and sixteen (316) pregnant women. The sero-prevalence of Herpes simplex virus type-2 was determined using an enzyme linked immunosorbent assay while levels of cellular immune status $\left(\mathrm{CD}_{4}{ }^{+}\right)$and inflammation markers (C-reactive protein, total leukocyte count, total lymphocyte count, plasma viscosity) were determined using standard procedures. Result: The prevalence of HSV-2 was 192 (60.8\%). Mean C-reactive protein and lymphocyte concentration were significantly higher in HSV-2 sero-positive subjects than in sero-negative counterpart (15.63 vs. $11.02, \mathrm{p}<0.001)$ and $(41.90$ vs. 33.71, $\mathrm{p}<0.001)$ respectively, but $\mathrm{CD}_{4}{ }^{+}$count did not differ in both subject group ((1114.39 vs. 988.21, 95\% C.I 55.493, 196.86, $\mathrm{P}=0.076$ ). Also the levels of total white cell count and plasma viscosity were not significantly different in HSV-2 sero-positive and sero-negative subjects. Conclusion: Increased levels of C- reactive protein and total lymphocyte count were significantly associated with HSV-2 infection. Increased CRP levels are known to contribute to atherogenic process; its routine quantification in patients managed for herpes infection is however advised.
\end{abstract}

Keywords: HSV-2, Cellular immune status, $\mathrm{CD}_{4}{ }^{+}$, C-reactive protein, Genital ulcer. 


\section{Introduction}

Herpes simplex virus type-2 is now recognized as a significant cause of genital ulcer disease worldwide [1]. Genital herpes can be caused by either herpes simplex virus type 1 (HSV-1) or type 2 (HSV-2) but, worldwide (over 90\%) of cases are caused by HSV-2 [1].

The immunologic response against HSV-2 includes both innate and adaptive immune response. The innate immune response is more profound and constitutes a major factor in determining the prognosis of an infection with HSV-2. The profound production of interferons of $\alpha$ and $\beta$ types has been shown to lead to protection against HSV-2 induced diseases in documented studies in mouse models and human studies [2]. Potent neutralizing antibody production via adaptive immune response has also been documented to negatively correlate with disease severity [2].

Also $\mathrm{CD}_{4}{ }^{+} \mathrm{T}$ cells are very essential in controlling HSV-2 infection [3]. This is evident from the fact that $\mathrm{CD}_{8}{ }^{+}$deficient human experimental subjects do not suffer from any viral infections caused by the Herpesviridae, whereas $\mathrm{CD}_{4}{ }^{+-}$deficient AIDS patients do [4]. $\mathrm{CD}_{4}{ }^{+} \mathrm{T}$-cell responses to HSV-2 appear to be directed against envelope glycoproteins, capsid proteins and regulatory elements within the tegument [3].

There is accumulating evidence that some agent of sexually transmitted diseases notably $\mathrm{HSV}-2$ can cause induce inflammation in humans [5], with consequent induction of production of cytokines and acute phase response both locally and systemically with chemo tactic cytokine release into the peripheral circulation with the production of acute phase response (pyrexia, leukocytosis etc.) and mobilization of lymphocytes and neutrophil which may indirectly influence the course of atherosclerosis [6]. This could raise levels of inflammatory markers in systemic circulation with consequent deleterious activity on cardiovascular system and a possibility of coronary artery disease (CAD) [7]. Progressive depletion in polymorphonuclear cells has been hypothesized to be a significant risk factor for genital herpes acquisition [7]. Also, a low white blood cell count may lead to reactivation of genital herpes [7].

The study aimed to determine the cellular immune status $\left(\mathrm{CD}_{4}{ }^{+} \mathrm{T}\right.$ cell count $)$ and levels of systemic inflammation markers (C-reactive protein (CRP), Total lymphocyte count, Plasma viscosity and Total white cell count) in Herpes simplex virus type-2 sero-positive pregnant women in Warri, Southern, Nigeria.

\section{Materials and Methods}

\subsection{Study Area}

This study was conducted at the antenatal clinic of the Department of Obstetrics and Gynaecology, Central Hospital, Warri, Delta state, Nigeria. This hospital is the major government owned tertiary heath facility in Delta central senatorial district, it also house the antenatal clinic annex of Delta state university teaching hospital, Oghara.

\subsection{Study Design}

This study was a cross-sectional descriptive study to evaluate cellular immune status and inflammatory markers in Herpes simplex virus type -2 positive pregnant women (15 to $>40$ Yrs) attending antenatal clinic of Central Hospital, Warri, Delta state, Nigeria. The subjects used for this study was chosen by stratified random sampling technique at the antenatal clinic.

\subsection{Study Population and Selection Criteria}

The study population included three hundred and sixteen (316) pregnant women between the ages of 15 and $>40$ years. Inclusion criteria included been pregnant, no drug history, no chronic disease, no pregnancy induced hypertension, non-smoking and no high risk pregnancy.

\subsection{Ethical Approval}

Informed consent (Written or verbal) was obtained from subjects before recruitment for this study. The protocol for this study was approved by the ethics committee of Delta State Hospitals Management Board, Warri Medical Zone 
(Central hospital, Warri) in the letter CHW/ECC/VOL1/48.

\subsection{Sample Collection and Preparation}

About $10 \mathrm{ml}$ of Blood sample was obtained by vein-puncture; equal volumes were dispensed into EDTA bottles and plain containers. Samples were securely and clearly labeled with codes corresponding to a subject name to prevent mismatch and misinterpretation of result. Grossly haemolysed and hyperlipaemic samples were discarded as they could generate false positive result. In general, phlebotomy errors that could undermine final results were minimized.

Total white cell, $\mathrm{CD}_{4}{ }^{+}$and lymphocyte count were determined in the EDTA samples within 2 hrs of collection. Blood samples were allowed to settle down and Serum and plasma was separated using a bucket centrifuge calibrated to run at a speed of 2000 Revolutions per minute (RPM). . Remainder plasma was stored frozen for diagnosis of HSV-2 IgG and IgM. Serum samples were used to estimate levels of $\mathrm{C}$-reactive protein and plasma viscosity.

\subsection{Sample Analysis}

Analysis of specimens was carried out at the Institute of human virology Nigeria (IHVN) laboratory located at Central Hospital, Warri and Immunology laboratory of Department of Chemical pathology, University of Benin Teaching Hospital, Benin City, Nigeria.

\subsubsection{Herpes simplex virus type 2 IgG and IgM ELISA (Enzyme linked immunosorbent assay)}

HSV-2 (IgG and IgM) antibodies was determined using type specific (HSV glycoprotein G) Herpes simplex virus type 2 ELISA IgG and IgM kits (Dia pro diagnostics, Milan Italy), and the results was interpreted following manufacturers specifications.

\subsubsection{Principle of HSV-2 ELISA Test}

The type specific HSV 2 IgG and IgM ELISA is based on a solid phase enzyme-linked immunosorbent assay (ELISA). The assay uses affinity purified HSV type 2 antibodies for solid phase (microtiter wells) immobilization and horseradish peroxidase (HRP) conjugated anti-
HSV type 2 antibodies for detection. The test sample is diluted and incubated in the microtiter wells for 45 Min. The microtiter wells are subsequently washed and HRP conjugate is added and incubated for 30 minutes. This result in HSV type 2 molecules being sandwiched between the immobilization and detection antibodies. The wells are then washed to remove unbound HRP-labelled antibodies and TMB Reagent is added and incubated for 20 Min at room temperature. This results in the development of a blue colour. Colour development is stopped by the addition of Stop Solution, changing the colour to yellow, and optical density is measured spectrophotometrically at $405 \mathrm{~nm}$. The concentration of HSV type 2 is proportional to the optical density of the test sample. A calibration curve, calibrated against an internal Gold standard, makes possible a quantitative determination of the antibodies in the patient.

\subsection{3 $\mathrm{CD}_{4}{ }^{+} \mathrm{T}$ Cell Count}

Blood samples were analysed for $\mathrm{CD}_{4}{ }^{+} \mathrm{T}$ cell estimation using flow cytometry. (Partec, $\mathrm{GmbH}$, Germany). The partec Cyflow SL_3 is a single platform, three-parameter (SCC plus two colour fluorescence) desktop flow cytometer. It contains a solid laser for green excitation. It analyses concentrations of any particle or cell subpopulation of interest, using true volumentric absolute counting. The partec $\mathrm{CD}_{4} \%$ reagent kit used contained direct immunofluorescence reagents for enumeration of mature $\mathrm{CD}_{4}^{+}$ lymphocytes. Reference values for $\mathrm{CD}_{4} \mathrm{~T}$ lymphocyte count in apparently healthy humans is $>450 \mathrm{CD}_{4}^{+}$lymphocytes/ $\mu 1$.

\subsubsection{Procedure for $\mathrm{CD}_{4}{ }^{+} \mathrm{T}$ cell estimation}

$20 \mu \mathrm{l}$ of $\mathrm{CD}_{4}{ }^{+} \mathrm{PE}$ antibody was dispensed into a partec test tube and $20 \mu \mathrm{l}$ of well mixed whole blood was added, mixed gently and incubated in the dark for $15 \mathrm{~min}$ at room temperature. The mixture was agitated during incubation every 5 Mins. $800 \mu \mathrm{l}$ of $\mathrm{CD}_{4}$ buffer was added to the mixture of antibody and sample and mixed gently. This was then plugged to the counter for counting. 


\subsubsection{Total leukocyte and Lymphocyte count}

Total leukocyte and lymphocyte counts were determined in EDTA blood containers using Sysmex kx-21N hematology auto analyzer instrument [8]. Reference value for Total leukocyte count and total lymphocyte count in humans is 4000- $1000 / 1$ and 25-40 \% respectively.

\subsubsection{C- reactive protein $(\mathrm{CRP})$ estimation}

The Turbitest AA Line (Wierner laboratories, S.AI.C, Argentina) C reactive protein test kit based on immunoturbidimetry was used for the quantitative determination of serum levels of $\mathrm{C}$ reactive protein in subjects studied. The detection limit of this kit i.e., the minimum analyte amount capable of being detected as a sample, different than zero, and corresponds to the concentration of $0.5 \mathrm{mg} / \mathrm{l}$. Its linearity (Assay range) is from $2 \mathrm{mg} / \mathrm{l}$ to $200 \mathrm{mg} / \mathrm{l}$ CRP approximately. Assay conditions: wavelength $(340 \mathrm{~nm})$, reaction temperature $\left(37^{\mathrm{O}} \mathrm{c}\right)$, reaction time (10mins), sample volume $80 \mu \mathrm{l}$ ) and final reaction volume $(1.28 \mathrm{ml})$. Provided reagents: Calibrator (Calibrador en serie, 1;3;5;6;7;and 8), Reagent A (Saline buffer solution, Ph 7.6) and Reagent B (monospecific anti-CRP antibodies). Chemwell 2910 (Automated EIA and chemistry analyser) (Manufactured by Awareness technology, Incorporated, Palm City, United States of America) was used for measurement of absorbance of test and calibrators.

The reference range for CRP in apparently healthy individuals is $<10 \mathrm{mg} / \mathrm{L}$.

\subsubsection{Determination of Plasma Viscosity}

A modification of the method of Reid and Ugwu., (1987) was used. A 1ml syringe with a hypodermic needle $(21.6 \times 0.8 \times 4 \mathrm{~mm})$ was used. Briefly, plasma was drawn into the syringe, avoiding air bubbles, till the $1.0 \mathrm{ml}$ mark. The plunger was carefully, removed and the time taken for the entire plasma to drain was noted. This was done twice for each sample and the average taken for that sample. The entire process was repeated using distilled water. The plasma viscosity is the ratio of the flow rate of plasma to that of water.

\subsection{Data analysis}

Data was analyzed using SPSS v. 16. Seroprevalence was reported in percentages and comparism of prevalence with cellular immune status and inflammatory markers was done using chi square test, ANOVA and Fischer's exact were necessary.

\section{Result}

The Mean age of the study subjects at enrolment was 29 years $(\mathrm{SD} \pm$ 4.8). Table 1 summarizes the obstetric characteristics of the study population. Among the enrolled subjects, $44.3 \%(n=140)$ was in their $2^{\text {nd }}$ trimester, $43.0 \%$ $(n=136)$ was in their third trimester while subjects in their $1^{\text {st }}$ trimester had the least numbers of participants in this study $12.7 \%$ $(n=40)$.

The prevalence of antibodies to HSV-2 is presented in Table 2. The total prevalence of HSV-2 was 192 (60.8\%).

Table 3 summarizes the mean concentration of cellular immune parameters $\left(\mathrm{CD}_{4}{ }^{+}\right.$cell count, Total Leukocyte count, Total lymphocyte count, C- reactive protein and Plasma viscosity) of study participants. The mean $\mathrm{CD}_{4}{ }^{+}$and total white cell count were within reference range $(400-1800 / \mu 1$ and 4000-10000/1 respectively).

The association between Herpes simplex virus type-2 sero-positivity and inflammatory markers is presented in Table 4. Mean C-reactive protein and lymphocyte concentrations were significantly higher in Herpes simplex virus type2 positive subjects than in sero-negative subjects $(15.63$ vs. $11.02,95 \% \quad \mathrm{CI}=-5.997,-3.220$, $\mathrm{p}<0.001)$ and $(41.90$ vs. 33.71, 95\%, $\mathrm{p}<0.001)$ respectively, but there was no significant difference between total white cell count in HSV2 positive and negative subjects (Mean: 5600.00 vs. 5618.75, $\mathrm{p}=0.895) . \mathrm{CD}_{4}{ }^{+}$count were higher in Herpes simplex virus type-2 sero-negative subjects when compared to their sero-positive counterparts but this was not significantly different (1114.39 vs. 988.21, 95\% CI=55.493, 196.864, $\mathrm{P}=0.076$ ) Table 5. 
Table 1: Obstetric characteristics of pregnant women attending the antenatal clinic of Central Hospital, Warri

\begin{tabular}{lll}
\hline Parameters & Frequency & Percentage $(\%)$
\end{tabular}

\section{Marital status}

Married

276

87.3

Single

32

10.1

Divorced

8

2.5

Trimester

$1^{\text {st }}$

$2^{\text {nd }}$

Parity status

Primigravidae

Multigravidae

Coitarchal age (Age at first sexual debut)

$\leq 16$

$>16$

Symptomatic (Clinical) Genital Ulcer disease

Yes

No

History of genital ulcer disease

Yes

No

History of spontaneous Abortion

Yes

No
36

280

49

267

28

288
8.9

11.4

88.6

15.5

84.5

91.1

Table 2: Prevalence of Latent, reactivated and new HSV-2 infection among pregnant women attending the antenatal clinic of Central Hospital, Warri

\begin{tabular}{lcc}
\hline Herpes simplex virus type-2 sero-status & Number & Percentage \\
\hline Positive & 192 & $(60.8)$ \\
No infection & 124 & $(39.2)$ \\
\hline
\end{tabular}


Table 3: Concentration of cellular immune parameters among pregnant women attending the antenatal clinic of Central Hospital, Warri

\begin{tabular}{lll}
\hline Parameter & \multicolumn{2}{l}{ Mean \pm Standard Deviation } \\
\hline $\mathrm{CD}_{4}{ }^{+}$count & 1037.72 & \pm 317.394 \\
Total White cell count & 5611.39 & \pm 1224.925 \\
Total Lymphocyte count & 38.68 & \pm 11.880 \\
Plasma Viscosity & 1.66 & \pm 0.134 \\
C-reactive protein & 13.82 & \pm 6.517
\end{tabular}

Table 4: Association between HSV- 2 status and systemic inflammatory markers among pregnant women attending the antenatal clinic of Central Hospital, Warri

\begin{tabular}{ccc}
\hline Parameter HSV-2 status & Mean \pm S.E & P value \\
\hline White cell count & $5600.00 \pm 93.199$ & 0.294 \\
Negative 124 & $5618.75 \pm 96.307$ & \\
Positive 192 & & $0.020^{*}$ \\
Lymphocyte count & $33.71 \pm 0.684$ & \\
Negative 124 & $41.90 \pm 0.938$ & \\
Positive 192 & & $0.024^{*}$ \\
C- reactive protein & $11.02 \pm 0.310$ & \\
Negative 124 & $15.63 \pm 0.530$ & 0.267 \\
Positive 192 & & \\
Plasma Viscosity & $1.62 \pm 0.010$ & \\
Negative 124 & $1.69 \pm 0.010$ & \\
Positive 192 & &
\end{tabular}

*Statistically significant

Table 5: Association between HSV- 2 status and cellular immune status among pregnant women attending the antenatal clinic of Central Hospital, Warri

\begin{tabular}{|c|c|c|c|}
\hline Parameter & Mean \pm S.E & 95\% C.I & $P$ value \\
\hline \multicolumn{4}{|l|}{$\mathrm{CD}_{4}^{+}$} \\
\hline Negative 124 & $1114.39 \pm 21.172$ & $55.493,196.864$ & $\mathrm{P}=0.076$ \\
\hline Positive 192 & $988.21 \pm 25.420$ & & \\
\hline
\end{tabular}




\section{Discussion}

This study determined the association between HSV-2 sero-positivity and cellular immune parameters with focus on $\mathrm{CD}_{4}{ }^{+} \mathrm{T}$ lymphocyte count and inflammatory markers among pregnant women. Increased lymphocyte count in HSV-2 sero-positive subjects in this study agrees with the report of an earlier study [9]. Lymphocytes are made by the immune system to fight disease. An increase in circulating lymphocytes is a sign of viral infection and is most commonly seen in lymphoproliferative disorders or in recurrent or new Herpes simplex virus infection [9].

In this study C- reactive protein was significantly higher in HSV-2 sero-positive subjects than those without infection. C-reactive protein (CRP) is a biomarker of acute phase response which is known to typically elevate in blood as a result of inflammation. It has been observed that pathogen induced inflammation may contribute to atherogenic process that may lead to coronary heart disease (CAD) [6]. An association between increasing burden of antibodies to persistent viral infections and increased levels of CRP and CAD was found in a study that tested the association of a five panel of pathogens (Cytomegalovirus, HSV-1, HSV-2, Chlamydia and Hepatitis A virus) to CAD risk [10].

Other studies [11,12], have also shown that increasing burden of persistent viral infection such as HSV-2 leads to increased endothelial dysfunction which is one of the earliest signs of atherosclerosis. Epstein [6], summarized that apart from the ability of persistent viral infections to contribute to atherosclerosis, they can also trigger plaque rupture and acute thrombotic occlusion which are major factors in acute myocardial infarction and for sudden deaths in patients with CAD.

The $\mathrm{CD}_{4}{ }^{+}$cell count in HSV- 2 sero-positive pregnant women was lower $(988.21 \pm 25.42)$ than their sero-negative counterparts $(1114.39 \pm 21.172)$ but were not statistically different. Our study shows that HSV-2 does not lead to $\mathrm{CD}_{4}{ }^{+}$cell decline unlike the Human immunodeficiency virus (HIV) with tropism for $\mathrm{CD}_{4}{ }^{+}$cells. In a recent study, there was no association between $\mathrm{CD}_{4}{ }^{+} \mathrm{T}$ cell counts and HSV-1 or HSV-2 sero-status in a proof of concept study among pregnant women in Limpopo, South Africa [13]. Similarly a study among postpartum women in Kenya did not find any significant association between $\mathrm{HSV}-2$ infection and $\mathrm{CD}_{4}{ }^{+} \mathrm{T}$ cell decline [14]. Our result does not agree with the study of Barnabas et al [15], which reported a an association between CD4 count decrease and HSV-2 infection [15]. The non- association between HSV-2 infection and CD4+ cell decline has also been proven in a United States epidemiology study Hoots et al., [16].

Total white cell count and plasma viscosity were not associated with HSV-2 sero-positivity, this indicates that they may not be useful indicators for non-specific evaluation for HSV-2. Plasma viscosities have been hypothesized to be a useful non-specific marker for inflammation in HIV [17], that assertion was unable to be proven in this study for its utility in HSV-2. The low concentration of plasma viscosity in subjects in our study is thought to be influenced by packed cell volume which has been found to be generally low among pregnant women in sub-Saharan Africa [18].

\section{Conclusion}

There were no statistically significant association between HSV-2 sero-positivity and $\mathrm{CD}_{4}{ }^{+} \mathrm{T}$ cell counts levels, plasma viscosity and total white cell count. It can be hypothesized that HSV-2 does not cause $\mathrm{CD}_{4}{ }^{+}$cell decline and its routine measurement in management of $\mathrm{HSV}-2$ mono-infection in a resource limited setting such as ours might be of no diagnostic value except when there is HIV co-infection. C-reactive protein and total lymphocyte count were significantly associated with HSV-2 sero-positivity indicating a causal role of HSV-2 in inflammation. Increased CRP levels are known to contribute to atherogenic process; its routine quantification in patients managed for herpes infection is however advised.

\section{Acknowledgement}

Authors wish to appreciate with thanks technical assistance of $\mathrm{Mr}$ Paul Aikorogie 
(FMLSCN) of the Chemical Pathology laboratory, University of Benin, Benin City, Nigeria. Authors thank the participants for their cooperation in carrying out this study.

\section{Funding}

This study was personally funded by authors. The corresponding author received gifts of laboratory test kits from Prevention, Education, Training, Treatment and Research - Global Solutions (PeTR-GS) partners of Lily VCT centre. PeTR-GS had no input in the design, collection, analysis or interpretation of data, in writing the report or in the decision to submit.

\section{References}

1. Pickering JM, Whitworth JA, Hughes P, Kasse M, Morgan D, Mayanja B. Aetiology of sexually transmitted infections and response to syndromic treatment in southwest Uganda. Sexuallly Transmitted Infection 2005; 81: 488-493. DOI: 10.1136/sti.2004.013276. PMCID: PMC1745059

2. Herbst-Kralovetz M, Pyles R. Quantification of poly(I:C)-mediated protection against genital herpes simplex virus type 2 infection. J Virology. 2006; 80: 9988-9997. DOI: 10.1128/JVI.01099-06

3. Erikson K, Bellner L, Staffan GOR, Gun-Britt LW, Tunba P, Rydberg $\mathrm{K}$ et al. $\mathrm{CD}_{4}{ }^{+} \mathrm{T}$-cell responses to Herpes simplex virus type 2 (HSV- glycoprotein G are type specific and differ in symptomatic and asymptomatic HSV-2-infected individuals. J Gen Virology 2004; 85: 2139- 2147. DOI: 10.1099/vir.0.79978-0

4. de la Calle-Martin O, Hernandez M Ordi J, Casamitjana N, Arostegui JI, Caragol I et al. Familial CD8 deficiency due to a mutation in the CD8 alphagene. J Clin Invest 2001; 108: 117-123.

5. Shinkatu M, Umehara Y, Iwaisako K, Tahera M, Adachi Y. Herpes Simplex pancreatitis . Arch Path and Lab Medicine 2003 127: 231234.

6. Epstein E. (2002). The multiple mechanisms by which infection may contribute to artherosclerosis development and course. Circulation research 90: 2-4.

7. Kerry J, Amalia S L, Magaret DE, Mueller L, Zhao SC, Johnston $\mathrm{C}$ et al. Diversity in $\mathrm{CD}^{+}$ T Cell Function and epitope Breadth among Persons with Genital Herpes. J Clin Immunol 2201; 67:65-73.

8. Hedwin, Seiko E, Hewlett E I and Nemour P. (2008) Sysmex auto analyzer model KX-2IN Version. Sysmex Corporation.

9. Plastaris SC, Kampessi OS. (2009) Acute lymphocytic crisis following herpes simplex type 1 virus hepatitis in a nonimmunocompromised man: a case report. $J$ medical case reports 2009; 3: 3-7. DOI: 10.1186/1752-1947-3-7

10. Zhu J, Quyyumi AA, Norman JE, Csako G, Waclawiw MA, Shearer GM et al. Total pathogen burden contributes incrementally to coronary artery disease risk and to C-reactive protein levels. Am J Cardiol 2000; 85: 140 146.

11. Zhu J, Nieto JF, Horne BD, Anderson JI, Muhlestein JB, Epstein SE. Prospective study of pathogen burden and risk of myocardial infarction or death. Circulation. 2001; 103: 45-51.

12. Rupprecht HJ, Blankenberg S, Bickel C, Rippin G, Hafner G, Prellwitz W, Schlumberger W, Meyer J. Impact of viral and bacterial infections burden on long-term prognosis in patients with coronary artery disease. Circulation. 2001; 104: 25-31.

13. Schaftenaar E, Verjans GM, Getu S, Mcintyre JA, Struthers HE. (2014). High seroprevalence of Human herpes in HIVinfected individuals attending primary health care facilities in Rural SouthAfrica. Public library of science (PLOS) one 9: e 99243.

14. Roxby AC, Drake AL, John-Stewart G, Brown ER, Matemo D, Otieno PA, Farquhar C. Herpes simplex virus type 2 , genital ulcers and HIV-1 disease progression in postpartum women. PLoS One. 2011; 6:e19947. DOI: 10.1371/journal.pone.0019947.

15. Barnabas RV, Wasserheit JN, Huang Y, Janes $\mathrm{H}$, Morrow R, Fuchs $\mathrm{J}$ et al. Impact of herpes simplex virus type 2 on HIV-1 acquisition and 
progression in an HIV vaccine trial (the Step study). J Acquir Immune Defic Syndr 2011;57: 238-244.

16. Hoots BE, Hudgens MG, Cole SR, King CC, Klein RS, Mayer $\mathrm{KH}$ et al., Lack of association of herpes simplex virus type 2 seropositivity with the progression of HIV infection in the HERS cohort. Am J Epidemiol. 2011;173(7): 837.

17. Omoregie R, Adeghe JE, Ogefere HO,
Omokaro EU, Ekeh, CC. (2008). Haemorheologic and fibrinolytic activity in Nigerian HIV infected patients. Afr health sci 2008; $8:$ 217-219.

DOI: org/10.4314/ahs.v16i1.8

18. Imoru, M. and Emeribe, A.O. (2009). Haemorheologic and fibrinolytic activities in pregnant women: Influence of gestational age and parity. African journal of biotechnology 8: 23-26. DOI: org/10.5897/AJB2015.15125 